\title{
THE TRIAL JUDGE: PILOT, PARTICIPANT, OR UMPIRE?
}

HUGH W. SILVERMAN, Q.C.*

\begin{abstract}
The recent decision in Phillips $v$. Ford Motor Co. of Canada Ltd. et al., has reopened a question which some might have considered to be somewhat settled: the role and function of the trial judge. Professor Silverman has taken the Phillips decision as a cue for making a comprehensive analysis of the English and Canadian case law concerning the trial judge's function, in civil as well as criminal cases. Such issues as the rule requiring the presentation of evidence in open court, the limitations on the trial judge's right to call witnesses, his interference in the examination of witnesses and his intervention in the trial as a whole are examined. Professor Silverman notes that although there may be dicta in some criminal and civil cases which apply to both, the better approach for the trial judge is to restrict himself "as much as possible" to the principles set out in cases of the same nature (criminal or civil) as the one before him. However, the author does lay down several general propositions delineating the boundaries of the trial and the role of the trial judge, which are applicable to both criminal and civil cases. Professor Silverman concludes, that although a trial judge may be a pilot he "is certainly more than an umpire, watching the sporting-theory of litigation in action; and he is less than a participant in that he should not enter into the fray of combat nor take on the mantle of counsel".
\end{abstract}

\section{INTRODUCTION}

One would have thought that by now the role of the trial judge has been sufficiently delineated and explained to preclude the necessity for further judicial exposition upon this subject. However, the recent decision of the Ontario Court of Appeal in Phillips v. Ford Motor Co. of Canada Ltd. et al. ${ }^{1}$ indicates that this subject-matter is alive and open to debate.

\section{THE DECISION IN PHILLIPS}

The plaintiffs sued Ford Motor Company and one of its dealers alleging that an accident which occurred was the result of brake failure caused by defective manufacture, installation and servicing of the brakes in their motor vehicle.

Schroeder J.A. (with whom MacKay J.A. concurred) found that the defendants were not negligent and he would have dismissed the action against the defendants with costs. The majority reasons were rendered by Evans J.A. (with whom Kelly and Brooke JJ.A. concurred) who held that by reason of the trial judge's conduct a new trial should be ordered.

Haines J. at the trial, pursuant to the provisions of Rule $267^{2}$ appointed an assessor who took an active part in the trial by examining and cross-examining witnesses; ordered the defendants to provide the court with an operational manual for the vehicle involved; ordered

\footnotetext{
- Professor, Faculty of Law, University of Windsor.

: [1971] 2 O.R. 637.

2 Rule 267 reads as follows: (1) The court may obtain the assistance of merchants, engineers, accountants, actuaries, or scientific persons, in such way as it thinks fit, the better to enable it to determine any matter of fact in question in any cause or proceeding, and may act on the certificate of such person. (2) The court may fix the remuneration of any such persons and may direct payment thereof by any of the parties. (3) Unless all parties are sui juris and consent, the powers conferred by this rule shall only be exercised by or by leave of a judge.

In view of the Phillips decision quaere whether Blowes v. Hamilton [1970] 1 O.R. 310 where Stewart J., in a personal injury action, appointed a medical doctor as an assessor, under this Rule, to assist in determining facts, has been overruled; and he said (at 313) that the doctor can ask questions directly of witnesses (although it is worthy of note that Stewart J. said that he was obliged to take this course because defence counsel refused to disclose the medical theory of the defence until final argument).
} 
defendants to provide the court with a cut-away model of a portion of the braking system; adjourned court to go to testing laboratories at the University of Toronto where tests were made, but no record of them was kept; and he suggested during the trial that the plaintiffs undergo certain medical examinations and, as Evans J.A. points out: ${ }^{3}$

... took over a substantial part of the examination and cross-examination of several witnesses and seriously hampered counsel in the presentation of the evidence which he was leading and in the testing of evidence led by the opposing party.

Evans J.A. concluded that a new trial must be held because:

(1) "A trial", he said, "is not intended to be a scientific exploration with the presiding Judge assuming the role of a research director; it is a forum established for the purpose of providing justice for the litigants"4;

(2) A trial judge must be objective, dispassionate and refrain from "constant intervention"5;

(3) A trial conducted under the adversary system may not lead to the production of ultimate truth, but it is a "workable system"6 and the evidence produced there must be confined to the issues defined by the pre-trial proceedings (pleadings, particulars, examinations for discovery). ${ }^{7}$

The Phillips decision raises many issues about the role of the trial judge in a civil trial, and this, as well as his role in criminal trials, will now be examined.

\section{CIVIL TRIALS}

\section{England}

In Phillips Mr. Justice Evans refers to Jones v. National Coal Board ${ }^{8}$ and Majcenic v. Natale $^{9}$ as delineating the function of the trial judge in a civil action.

In Jones v. National Coal Board the English Court of Appeal ordered a new trial where it felt that the trial judge had improperly intruded into the conduct of the trial. Denning L.J. (as he then was) gave the court's reasons, per curiam, and these are the highlights of his comments about the trial judge's functions:

(1) He says: ${ }^{10}$

... the judge sits to hear and determine the issues raised by the parties, not to conduct an investigation or examination on behalf of society at large. . . Even in England, however, a judge is not a mere umpire to answer the question 'How's that?' His object, above all, is to find out the truth, and to do justice according to law.

And he refers with approval to the remarks of Lord Greene M.R. in

${ }^{3}$ Phillips v. Ford Motor Co. of Canada Ltd. et al., supra, n. 1 at 659.

1 Id. at 657 .

s Id. at $657,658$.

- Id. at 657 .

IId. at 661 .

8 [1957] 2 Q.B. 55, [1957] 2 All. E.R. 155.

9 [1968] 1 O.R. 189, 66 D.L.R. (2d) 50 (C.A.). For a discussion of this case and other recent decisions see Watson and Barber, Annual Survey of Canadian Law-Part 1-Civil Procedure, (1970) 4 Ottawa L. Kev. 132 at 167-175.

10 Supra, n. 8 at 63 (Q.B.). Cf. Winick, A Primer of Psychological Theories Holding Implications for Legal Work, vii The American Behavioral Scientist 45 at 46, (December, 1963, no. 4), who says that the "psychology of inter-personal relations is central [to judicial decision-makingl inasmuch as the judge is the umpire in the adversary procedure of the courts". 
Yuill v. Yuill ${ }^{11}$ that the trial judge's function is to keep a balance between litigants; refrain from entering into the arena of conflict by taking part in the actual conduct of examinations; rely only on the witnesses called by counsel ${ }^{12}$ whose function it is to examine the witnesses; ${ }^{13}$ and permit counsel to present his case ${ }^{14}$ and conduct a crossexamination ${ }^{15}$ without unnecessary interruptions.

(2) His oft-quoted statement of the trial judge's role is: ${ }^{16}$

The judge's part . . . is to hearken to the evidence, only himself asking questions of witnesses when it is necessary to clear up any point that has been overlooked or left obscure; to see that the advocates behave themselves seemly and keep to the rules laid down by law; to exclude irrelevancies and discourage repetition; to make sure by wise intervention that he follows the points that the advocates are making and can assess their worth; and at the end to make up his mind where the truth lies. If he goes beyond this, he drops the mantle of a judge and assumes the role of an advocate; and the change does not become him well.

And he continues: ${ }^{17}$

In the very pursuit of justice, our keenness may outrun our sureness, and we may trip and fall.

Lord Greene M.R. in Yuill v. Yuill ${ }^{18}$ makes it clear that a trial judge is not an active participant in the court proceedings, and should adopt an objective, detached attitude to the proceedings, and in particular should refrain from questioning witnesses except for the purpose of clearing up an obscure point, preferably after counsel has finished his examination, because he does not know what is in counsel's brief and cannot pre-determine the course and thrust of the examination. ${ }^{19}$

It has been said that a judge can call a witness which neither side has called, and he is the witness of the judge, the right to crossexamine being in the discretion of the judge; ${ }^{20}$ but such a witness can only be called "with the acquiescence of both parties" where neither party wants to call the witness and it is "desirable to have [the witness] before the court" 21 but this right does not extend to an umpire acting at an arbitration. ${ }^{22}$

" [1945] P. 15,61 T.L.R. 176, [1945] 1 All E.R. 183.

12 Supra, n. 8 at 64, on the authority of In re Enoch and Zaretsky, Bock \& Co's. Arbitration [1910] 1 K.B. 327.

13 Id. on the authority of Rex v. Cain (1936) 25 Cr. App. R. 204; Rex v. Bateman (1946) 31 Cr. App. R. 106, and Harris v. Harris, The Times, Apr. 9, 1952, Judgments of the Court of Appeal, 1952, No. 148.

if Id. on the authority of Reg. v. Clewer (1953) 37 Cr. App. R. 37.

is Id. at 65 where Denning L.J. says:

Excessive judicial interruption inevitably weakens the effectiveness of cross-examination for . . . it gives a witness valuable time for thought before answering a difficult question, and diverts cross-examining counsel from the course which he had intended to pursue, and to which it is by no means easy sometimes to return.

16 Id, at 64 .

17 Id.

18 Supra, n. 11.

19 Id. at 185, 189 (All E.R.).

20 Coulson v. Disborough [1894] 2 Q.B.D. 316 (C.A.). It has been held that fresh evidence arising after trial cannot be introduced on an appeal: Kessowje Issur v. Great Indian Peninsula Railway Company (1907) 96 L.T. 859 (J.C.P.C.); but a point of law which was not raised at the trial may be raised on an appeal: Banbury v. Bank of Montreal [1916] A.C. 626 (H.L.); sed quaere in view of the provisions of Ontario Rule 234 which provides that on all appeals fresh evidence may be heard. Prior to the delivery and entry of judgment the trial judge in the exercise of his discretion may receive fresh and new evidence: see Brett v. Brett [1937] 2 W.W.R. 689, aff'd. [1938] 2 W.W.R. at 372, [1938] 3 D.L.R. at 542 (Alta. C.A.); Rafferty v. Fisher (No. 2) (1952) 7 W.W.R. (N.S.) 565 (B.C.); Bauz v. Registrar of Motor Vehicles [1950] O.W.N. 386; and Hornak v. Paterson et al. (1966) 53 D.L.R. (2d) 566 (B.C.).

21 In re Enoch and Zaretsky, Bock \& Co's. Arbitration, supra, n. 12 at 333 per Fletcher Moulton L.J. See Nokes, An Introduction to Evidence 376 (4th ed. 1967) referring to Fallon v. Calvert [1960] 2 Q.B. 201 (C.A.) and a note in (1960) 76 L.Q.R. 341 says that "when a witness has been called by a party, the judge may recall him". In Fallon v. Calvert it was held that where an Official Referee was conducting 


\section{Canada}

In the main, Canadian decisions concerning the role and function of the trial judge have followed the English authorities. One of the recurring themes in the cases is the need for the appearance of justice notwithstanding anything else that may have transpired; hence frequent reference is made to the dictum of Lord Hewart C.J. : ${ }^{23}$

.. a a long line of cases shows that it is not merely of some importance but is of fundamental importance that justice should not only be done, but should manifestly and undoubtedly be seen to be done.

The Supreme Court of Canada has characterized a trial judge as an impartial arbitrator, who should not play the role of adviser to the parties; ${ }^{24}$ and he is not an umpire, ${ }^{25}$ nor a "mere machine" who can only act on a motion, as it is "his duty to see that in all things there is regularity and propriety";26 nor should he pre-judge the action. ${ }^{27}$

The rule requiring presentation of evidence and the presence of the parties and counsel in open court is given strong lip-service, and considered by some to be almost sacrosanct. ${ }^{28} \mathrm{~A}$ trial judge should not see the clients in his Chambers in the absence of their counsel and without a reporter being present; 29 and where the trial judge wants to see counsel in his Chambers about matters concerning the trial (where he prefers that these matters should not be heard in open court before a jury or in their absence), he should not indulge in "unrecorded discussion" in his Chambers but should arrange for a reporter to be present during such discussion..$^{30}$

Where, before rendering judgment, a trial judge receives evidence "not in open court and not in the presence of counsel", his judgment will be set aside. ${ }^{31}$ However, while some Chambers motions of an interlocutory nature need not be heard in open court, a Chambers motion which is in the nature of a trial (e.g., a landlord and tenant hearing) should not be heard in camera where the press and public are excluded. ${ }^{32}$ Tape recordings of evidence may be heard by a trial judge in his Chambers in the presence of counsel. ${ }^{33}$

a hearing pursuant to a judge's order, he could recall a witness who had already given evidence at the trial, as the hearing was a continuation of the trial which had not been finished with the customary final judgment; and, moreover, the court said, at 206, the right to recall a witness is not a "personal right of a particular judge" but rather belongs to the court "which is properly seised of the matter at the time in question."

22 Supra, n. 12 at 337 per Farwell LJ.

23 R. v. Sussex Justices, Ex p. McCarthy [1924] 1 K.B. 256 at 259 quoted, for example, in Delaney \& Co. Ltd. v. Berry and Berry (1965) 49 D.L.R. (2d) 171 at 173 (Man. C.A.). In Rex v. Darlyn, infra, n. 129 at 454 O'Halloran J.A. says the words "be seen" should read "seem;" but the tendency appears to be to use the words "be seen".

24 Bell et al. v. Smith et al. [1968] S.C.R. 664 at 673 per Spence J.

2s Majcenic v. Natale, supra, n. 9 at 203 (O.R.), although the Ontario Court of Appeal (Evans J.A.) also says he is not "Bolely" an arbitrator either. The Hon. Sir Patrick Devlin states in the 1956 Hamlyn Lectures, Trial by Jury 113, that the lawyer controls the collection and presentation of all material and "the judge is not an inquisator".

26 Gage v. Reid (1917) 38 O.L.R. 514 at 521 per Meredith C.J.C.P.

${ }^{27}$ Tecchi v. Cirillo [1968] 1 O.R. 536 (Ont. C.A.) where the trial judge pressed for a settlement, appeared to be partial, and read one of the examinations for discovery before it was tendered in evidence.

2s See McPherson v. McPherson [1936] A.C. 177, [1936] 1 D.L.R. 321 (J.C.P.C.).

25ell et al. v. Smith et al., supra, n. 24 at 672,673 per Spence J. This is not necessarily so in applications for custody of infants which is discussed hereafter.

30 Majcenic v. Natale, supra, n. 9 at 200, 201.

31 Ottewell v. Smith (1959) 28 W.W.R. 139 (Alta. A.D.).

32 Re Springman et al and Darragh (1969) I D.L.R. (3d) 250 (Man. C.A.) per Freedman J.A. (as he then was).

33 Zien v. Zien (1963) 40 D.L.R. (2d) 224 (B.C. C.A.). 
The extent of a trial judge's interference in the examination of witnesses was defined by Riddell J.A. in Boran v. Wenger: ${ }^{34}$

We think that it is the right of a litigant to have his case submitted to the trial
tribunal as his counsel thinks advisable and in the interests of his client-being
governed, of course, by the rules governing trial which are well-established and
recognized; the trial judge has no right to take the case into his own hands, and
out of the hands of counsel.
We do not for a moment suggest that the trial judge has not the right-it may often
be his duty-to obtain from the witnesses evidence in addition to that brought out
by counsel-but this is adjectival, to clear up, to add to, what counsel has brought
out.

Undue intervention by the trial judge during the examination and cross-examination of witnesses, on the principles established in Yuill v. Yuill ${ }^{35}$ and Jones v. National Coal Board, ${ }^{36}$ has been deprecated by Canadian courts. ${ }^{37}$

The trial judge's limited right to call witnesses, as explained in In re Enoch and Zaretzsky, Bock \& Co.'s Arbitration, ${ }^{38}$ has been approved in Jones v. National Coal Board. ${ }^{39}$ The converse, i.e. that counsel need not call his client, and it is of no concern to the trial judge if he adopts that course of action, has been approved in Harwood and Cooper v. Wilkinson..$^{40}$ In Harwood the plaintiff sued upon the covenants in two mortgages to recover principal and interest, and at the trial plaintiff's counsel put in the two mortgages and proved their execution, but did not call the plaintiff who was out of the country. The trial judge commented adversely upon this, ${ }^{41}$ and Riddell J.A. makes some sharp commentary upon this: ${ }^{42}$

Counsel was not asking nor need he ask favours of the court-he had no need of complaisance of the court; he owed no duty to the court but respect and honesty; he and not the court was the sole and only judge as to what witnesses to call. While the court may suggest, it has neither the duty nor the power to call a witness proprio motu in a civil case ... .; although, of course, he may recall one who has been examined . . . Counsel, not the Judge, is to determine what witnesses he is to call in support of his case; and while the Judge has the right to comment upon and base his judgment pro tanto on the non-production of any witness or witnesses, he has no right to criticise the discretion observed by counsel in so deciding-there may be a score of things that the counsel knows which the Judge cannot know that determine his decision, and he, not the Judge, is dominus litis. From an examination of the proceedings, I say with deliberation that I should never have thought of

3 [1942] O.W.N. 185 (Ont. C.A.) quoted with approval in Marjcenic v. Natale, supra, n. 9 at 204. The court said that while it disapproved of the proceedings, and considering that the trial judge permitted counsel "to add to what he had obtained by his own questions" (at 185), the error was not "so serious" (at 186) as to justify ordering a new trial.

3s Supra, n. 11 .

36 Supra, n. 8.

${ }^{37}$ Majcenic v. Natale, supra, n. 9; Pound v. National Cartage Company and Kroeker [1946] 1 W.W.R. 353 (Sask., C.A.); Thompson v. Thompson (1960) 22 D.L.R. (2d) 504 at 513 (Ont. C.A.) per Laidlaw J.A., [1961] S.C.R. 3 at 6 per Kerwin C.J. in his dissent; and Delaney \& Co. Ltd. v. Berry and Berry, supra, n. 23. See also Wilson v. Guthrie (1955) 15 W.W.R. 144 (Alta. A.D.).

3s Supra, n. 12. For a strict application of this case see Re Fraser (1912) 26 O.L.R. 508 at 521,522 (C.A.).

19 Supra, n. 8. See also Lindsay v. Imperial Steel and Wire Co. (1910) 21 O.L.R. 375 at 384 per Riddell J.; Coop v. Robert Simpson Co. (1918) 42 O.L.R. 488 at 504 per Riddell J.; and Re Settlement of Schnare (1935) 19 M.P.R. 378 at 386 (N.S. S.C., in banco).

10 (1929) 64 O.L.R. 658.

1T The trial judge also made adverse comments about plaintiff s refusal, upon the advice of counsel, to answer questions on discovery, and gave that as one of his grounds for dismissing the action. On the appeal it was properly pointed out that if there was such a refusal the appropriate procedure is to move for dismissal under the Rules of Practice (see now Rule 330).

12 Harwood and Cooper v. Wilkinson, supra, n. 40 at 662, 663 referring to In re Enoch, supra, n. 12, and Taylor on Evidence 1013, 1014 (11th ed.). See also French v. McKendrick (1930) 66 O.L.R. 306 at 309 per
Riddell J.A. 
calling the plaintiff in the present case. Counsel for the plaintiff is under no duty to the court, or to the opposite party, to call his client; he is to be governed solely by the interests of his client in the choice; and he need ask no favours from the Judge or any one else by reason of his determination. (emphasis added)

Moreover, it is a denial of justice for a trial judge to refuse to hear the witnesses who counsel wishes to call.43 In questioning a witness a trial judge has a discretion "as to the mode in which he may proceed to elicit facts" 44 and can ask leading questions and develop information where the testimony is defective (in the sense that something is unclear or has been omitted). 45

Specifically how should the trial judge proceed when he does question a witness? The Manitoba Court of Appeal delineated the boundaries and duties of a trial judge in this area in Nelson v. Murphy where Tritschler J.A. said: 46

Another ground of appeal is that the learned trial judge took a large part in the cross-examination of the defendant. At the conclusion of the examination and cross-examination of defendant the trial judge put a number of questions to him. It is the right and duty of a trial judge to question a witness if, in his view, that is necessary. There was no suggestion here of the judge interfering during the examination of the witness. If I may say so, with respect, the questions put by the learned trial judge at the conlusion of the examination and cross-examination were pertinent, searching and necessary in order to properly evaluate the testimony of the witness.

In Nelson v. Murphy, ${ }^{47}$ a negligence action brought by an injured pedestrian against the owner-driver of a motor vehicle, the proceedings were somewhat unusual in that the issue of the identity of the driver was to be tried and disposed of first before any other issues were determined. The driver's counsel, on' the appeal, alleged that the presiding trial judge at the end of the first day of trial "made a premature finding of liability before the whole of the defendant's case had been presented" 48 as he indicated satisfaction as to the defendant's identity, and Tritschler J.A. had this to say about that ground of appeal:49

Having heard the defendant's evidence and come to the end of the first day of trial and knowing that the further witnesses could not assist on the issue of identity it was practical and useful to inform counsel as did the learned trial judge. It is not objectionable for a trial judge in proper circumstances such as existed here, to express his opinion of a witness while he is giving evidence or immediately thereafter.

Where the trial judge in an undefended divorce action called the defendants as witnesses and examined them, followed by crossexamintion by plaintiff's counsel (who had neither objected nor consented to the calling of these witnesses), a new trial was ordered; 50 and it was said that the trial judge's conduct was that of counsel and not of a judge. ${ }^{51}$

4) Harper v. Griffiths (1929) 64 O.L.R. 668 per Riddell J.A.

- Connor v. Township of Brant (1914) 31 O.L.R. 274 at 286 per Hodgins J.A.

4. Id. at $283,285,286$.

46 (1957) 22 W.W.R. 137, 9 D.L.R. (2d) 195, aff'd. (1957) 21 W.W.R. 49 (Man. Q.B.).

i) Id.

4. Id. at 139 (W.W.R.).

4 Id. at 140.

so Fowler v. Fowler and Jackson [1949] O.W.N. 244. The court said there would be no costs of the appeal as plaintiffs counsel had cross-examined the witnesses.

s) Id. at 245. 
A trial judge has "complete discretion in determining how, when, where, and to what extent he will hear argument by counsel"52 and such argument may be oral or written;53 and he should not pronounce judgment without first giving counsel an opportunity to present argument (even if it is an undefended divorce action); 54 nor should he tell the jury, or counsel (where, as it turns out, he later dispenses with the jury), his opinion as to the quantum of general damages; ${ }^{55}$ and his judgment must be based upon the pleadings and proceedings in the action which define the issues, the evidence adduced at the trial in proof thereof, and it should be remembered that "having set the scene for the trial of the action on the single basis, and the case having been tried on that basis, it was not open to the plaintiff to rest its case on an alternative basis at the conclusion of the hearing."56

In actions for the custody of infant children we find that the trial judge may visit the home of the child together with counsel for the parties, 57 and may interview the infant there or in his Chambers with or without counsel, and with or without the parties; 58 but, in $R e$ Allan and Allan $^{59}$ where the trial judge interviewed the children in the absence of the parties and their counsel (who both consented to this private interview), and then relied upon information he received from the children but did not disclose this to the parties, the court deprecated this practice because: 60

The parties have the right to have the evidence taken in the presence of them and their counsel so that the witness may be subject to examination and crossexamination. ... The parties by their counsel ... waived the right to be present while the evidence was taken and to examine and cross-examine these infants. However, the waiver does not to go beyond that.

32 Schiach v. Schiach and Poulter [1941] 2 D.L.R. 590 per Taylor J. (Sask. K.B.).

53 Id. at $590,591$.

st Felker v. Felker [1946] O.W.N. 368 (Ont. C.A.); Tivy v. Tivy [1950] O.W.N. 839 (Ont. C.A.); and Wilson v. Guthrie, supra, n. 37.

ss Majcenic v. Natale, supra, n. 9; Gray v. Alanco Developments Ltd. [1967] 1 O.R. 597 (C.A.); reversing [1965] 2 O.R. 144 (H.C.J.); cf. Byron v. Williams [1968] S.C.R. 314, 67 D.L.R. (2d) 111 where Ritchie J. (at 112, D.L.R.) distinguished Gray on the ground that the decision in Gray was to the effect that the trial judge is precluded from expressing his opinion on general damages using figures of awards in other cases, and Hall J. (speaking for the majority, at 118, 119, D.L.R.) reserved Gray "for further consideration when the occasion arises" and held that in any event the jury assessment in Byron was reasonable; see the critical comment by Watson, Assisting the Jury in Assessing General Damages, (1970) 48 Can. Bar Rev. 565; and cf. Didluck v. Euans (1968) 67 D.L.R. (2d) 411 (Sask. C.A.) where the court approved of counsel telling the jury plaintiffs life expectancy in terms of a quantum of days and mentioned a minimum amount per day for damages, although not suggesting that this be used to compute damages. (Hall J.A. dissented on the basis inter alia of Gray). See also Allan v. Bushnell T.V. Co. Lid.: Broadcast News Led. Third Party [1969] 2 O.R. 6 (C.A.) to the effect that it is improper for counsel to tell a jury the quantum of damage awards in other cases.

so Per Jackett P. in Composers Authors and Publishers Association of Canada Led. v. CTV Television Network Ltd. (1966) 57 D.L.R. (2d) 5 at 14 (Ex. Ct.); aff'd. on appeal on other grounds, [1968] S.C.R. 676, 68 D.L.R. (2d) 98; Cosgrave v. Busk [1967] 1 O.R. 59 (C.A.); reversing [1966] 1 O.R.717, 55 D.L.R. (2d) 98; Re Dougmore Realty Holdings Lid., Fisher v. Wilgorn Investments Lid. [1968] 1 O.R. 61, 65 D.L.R. (2d) 420 (C.A.); rev'd. [1967] 1 O.R. 66, 59 D.L.R. (2d) 432. Cf. Five v. Hrapko and Lutzak [1936] 1 W.W.R. 627 (Alta. A.D.).

${ }^{57}$ Re McKee [1947] O.R. 819 at 835 per Wells J.

58 Id.; Re Kinne (1870) 5 P.R. 184; Re Faulds (1906) 12 O.L.R. 245 at 248; Brigden v. Brigden (1922) 23 O.W.N. 222; Re Steacy (1922) 52 O.L.R. 579; Re Laurin (1926-27) 60 O.L.R. 409, [1927] 3 D.LR. 136; $R e$ Orr [1933] O.R. 212; Re Purdy Infants [1945] O.W.N. 266; Clark v. Clark [1952] O.W.N. 671; Kelly v. Kelly (1968) 66 D.L.R. (2d) 696 at 698, 699 (N.S. S.C.); and Re DuBeau [1969] 2 O.R. 26 at 28 (Co. Ct). But ef. Re Krakat [1965] 2 O.R. 571 at 573 per Hughes J. (H.C.J.), where a Family Court judge, in proceedings dealing with a common assault charge, interviewed the complainant in her chambers in the absence of the accused, and although it was not indicated specifically what transpired in chambers, it was held that this procedure was "so remarkably improper" as to deprive the judge of jurisdiction.

59 (1959) 16 D.L.R. (2d) 172 (B.C.C.A.).

60 Id. at 182 per Sheppard J.A. who analogized between administrative tribunals and trial courts, and pointed out that the consent of counsel permitting the trial judge to see the children in private did not con. stitute a waiver of "their right to controvert the information thereby obtained." Furthermore, Sheppard J.A. (at 183) does not take kindly to the remark of the trial judge that in his interview with the children, in the presence of a clerk, he "simply sought to have them [the children] write the judgement for me." 
The learned trial judge in that interview obtained information on which he proposed to rely and it follows that such information should have been disclosed to the parties so that they might have had an opportunity of controverting it.

\section{CRIMINAL TRIALS}

\section{England}

The focus here will be upon two areas-the right of the trial judge to call witnesses, and his intervention in the trial. Newark and Samuels in their perceptive examination of the right of the trial judge to call witnesses ${ }^{61}$ point out inter alia that although the adversary system functions to develop truth, nevertheless it "may tend to suppress the truth." 62 In a criminal case a judge can call witnesses, and can do so of his own motion where the prosecution refuses to call an unreliable witness who will be favorable to the accused; and while he can call a witness at any stage of the trial, he should not do so at a late stage of the trial because this might necessitate an adjournment; ${ }^{64}$ there are no fixed rules as to the mode of questioning, however, neither counsel "has any right to cross-examine," but it is unlikely that the trial judge would preclude this especially if unfavorable evidence was developed. ${ }^{65}$ Newark and Samuels conclude that so long as the prosecution is not obliged to call all witnesses ${ }^{6}$ the problem of whether or not judges should call witnesses remains, and we should bear in mind that the trial judge should avoid "descending into the arena", 67 and:68

The fundamental issue is whether the criminal trial is a search for the truth or whether it is a contest conducted in the context of certain adversary rules. Many of the rules of criminal procedure, including the effective limitation on the power of the judge to call a witness, stem from our espousal of the adversary system.

What principles govern the calling of witnesses by the trial judge? At a murder trial, all witnesses on the back of the indictment should be called to give defence counsel the right to cross-examine them; 69 and all those witnesses present "at a transaction of this sort ought to be called even if they give different accounts."70 Once the defence is completed, it is within the discretion of the trial judge whether or not any rebuttal evidence can be called. ${ }^{71}$ One of the grounds advanced by Sir E. Marshall-Hall in the Starkie appeal ${ }^{72}$ was that the course of the trial had taken him by surprise, hence he asked for leave to call further evidence; and the court noted that the witnesses who counsel wished to call were available at the trial, hence where "counsel deliberately refrains from calling witnesses at the trial the court will be

61 Newark and Samuels, Let the Judge Call the Witness, [1969] Crim. L. Rev. 399 who mention and review the pertinent cases. Cf. The Trial Judge's Use of His Power to Call Witnesses-An Aid to Adversary Presentation, (1957) 51 Nev. U. L. Rev. 761.

62 Newark and Samuels, supra, n. 61.

63 Id. at 401 .

64 Id. at 402 .

6s Id. at 403.

60 Sed quaere, see infra, n. 69.

67 Yuill v. Yuill, supra, n. 11 per Lord Greene M.R. at 189 (All E.R.).

68 Supra, n. 61 at 404.

69 Rex v. Beezley (1830) 4 Car. \& P. 220, 172 E.R. 678; Regina v. Chapman (1838) 8 Car. \& P. 558,173 E.R. 617 ; but see Rex v. Harris, infra, n. 74.

7o Regina v. Holden (1838) 8 Car. \& P. 606 at 610 per Patteson J.

7 The King v. Crippen [1910] 1 K.B. 149.

72 (1921) 16 Cr. App. R. 61. 
slow to call them on the appeal, and will only do so in exceptional circumstances".73

The trial judge's right to call witnesses differs in criminal and civil trials. In Rex v. Harris, ${ }^{74}$ after the defence was completed, the trial judge called as a witness a convicted thief, who had been present in court throughout the trial of the accused, without suggesting or giving the accused the opportunity to rebut that evidence, and the court disapproved of that procedure. Consider the statements of Avory J. particularly as they indicate the different principles which should apply in civil and criminal trials: ${ }^{75}$

... it has been clearly laid down by the Court of Appeal in In re Enoch and Zaretsky, Bock \& Co. ... that in a civil suit the judge has no right to call a witness not called by either party, unless he does so with the consent of both of the parties. It also appears to be clearly established that that rule does not apply to a criminal trial where the liberty of a subject is at stake and where the sole object of the proceedings is to make certain that justice should be done as between the subject and the State. The cases of Reg. v. Chapman . . . and Reg. v. Holden ... establish the proposition that the presiding judge at a criminal trial has the right to call a witness not called by either the prosecution or the defence, and without the consent of either the prosecution or the defence, if in his opinion this course is necessary in the interests of justice.

Avory J. continues that there must be a limitation upon this right to avoid injury to the accused, and adopts the rule laid down by Tindal C.J. in Reg. v. Frost that: ${ }^{76}$

... if any matter arises ex improviso, which no human ingenuity can foresee, on the part of a defendant in a civil suit, or a prisoner in a criminal case, there seems ... no reason why that matter which so arose ex improviso may not be answered by contrary evidence on the part of the Crown.

Avory J., after noting that this "rule applies only to a witness called by the Crown and on behalf of the Crown" says it: ${ }^{77}$

.. . should apply also to a case where a witness is called in a criminal trial by the judge after the case for the defence is closed, and ... the practice should be limited to a case where a matter arises ex improviso, which no human ingenuity can foresee, on the part of a prisoner, otherwise injustice would ensue.

He concludes: ${ }^{78}$

In the circumstances, without laying down that in no case can an additional witness be called by the judge at the close of the trial after the case for the defence has been closed, we are of opinion that in this particular case the course that was adopted was irregular, and was calculated to do injustice to the appellant Harris.

The principles of Harris have been applied and followed; but in Liddle, ${ }^{79}$ where the defence of alibi was raised, and all the evidence was in, the trial judge adjourned the trial more than one time to call witnesses "on his own initiative" to show that one of the defence witnesses committed perjury, the court said that was not a matter which

i3 Id. at 63 .

74 (1927) 2 K.B. 587 (C.C.A.).

7s. Id. at 594 .

76 (1839) 4 St. Tr. (N.S.) 86 at 386, 9 C. \& P. 129 at 159, 169 E.R. 56. Cf. Shaw v. The Queen (1951) 85 C.L.R. 365.

"Supra, n. 74 at 595. See also R. v. Cleghorn [1967] 2 W.L.R. 1421, 51 Cr. App. R. 291, [1967] 1 All E.R. 996 where the trial judge issued a subpoena for a witness and called and examined that witness after the defence closed its case, allowing the prosecution and defence to cross-examine him; and the court said that if a witness is called in this way there must be no injustice or prejudice to the accused, and applying the dictum of Avory J. in Rex v. Harris, the conviction was quashed.

7 Supra, n. 74 at 596.

${ }_{7 y}$ (1930) 21 Cr. App. R. 3. 
had suddenly arisen ex improviso and this course was irregular and prejudicial to the accused. Where the defence takes the position that the prosecution has not made out a case, the "judge has a discretion to recall a witness," 80 however, "it may be undesirable to exercise the discretion with reference to such a crucial question as identity."81 After the summing up by the trial judge and the retirement of the jury, evidence on a fresh point was given by a prosecution witness in response to a vital and pertinent question asked by the jury in Reg. v. John Owen ${ }^{82}$ and the Court of Criminal Appeal said this was improper. Lord Goddard C.J. noted that the rule in Reg. v. Frost "is probably in wider language than would be applied today"83 and that a trial judge does have a discretion to allow rebuttal evidence to go in for the prosecution after the defence has closed where new matters have been raised by the defence; 84 and he concludes: ${ }^{85}$

The theory of our law is that he who affirms must prove, and therefore it is for the prosecutor to prove his case, and if there is some matter which the prosecution might have proved but have not, it is too late, after the summing-up, to allow further evidence to be given ... once the summing-up is concluded, no further evidence ought to be given.

In Sanderson ${ }^{86}$ though, a witness who the defence had intended to call arrived late during the summing-up, and the court said it was proper to call him as a witness. In Tregear ${ }^{87}$ two witnesses who testified in the court of first instance, and whose names appeared on the indictment were not called at the trial by the prosecution on the ground that they were unreliable, despite defence counsel's insistence that the prosecution was bound to call them. Defence counsel then called one of them, and after the close of the defence, the trial judge called the other witness and said that both counsel would have the opportunity to examine and cross-examine the witness. Davies L.J. rejected the defence contention that there is an inflexible rule that under no circumstances can a judge call a witness after the close of the defence case, because here the "judge considered it right, not in order to supplement the evidence for the prosecution, but to ascertain the truth and put all the evidence before the jury,"8s and although this was not a matter arising ex improviso the trial judge's conduct was proper.

80 Nokes, supra, n. 21 at 377 referring to R. v. McKenna (1956) 40 Cr. App. R. 65.

8: Id. referring to $R$. v. Van Der Vyuer [1961] Crim. L. Rev. 399 (C.C.A.).

A2 [1952] 2 Q.B. 362 (C.C.A.). Nokes, supra, n. 21 refers to R. v. Gaston [1963] Crim. L. Rev. 519 (C.C.A.) where it was held that it was proper for a prosecution witness, at the jury's request, to be recalled during the prosecution's final speech, the defence counsel not objecting to this and in fact proceeding to crossexamine the witness.

${ }^{83}$ Id. at 367.

84 Id. at 368. See generally The King v. Sullivan [1923] I K.B. 47, (1922) 16 Cr. App. R. 121 where rebuttal evidence was called by the trial judge after the defence closed its case and again after both counsel had addressed the jury, and this was held to be proper as an exercise of the trial judge's discretion, as the additional evidence was brought in not just for the purpose of re-stating previously tendered evidence. See also McKenna, supra, n. 80; and R. v. Van Der Vyver, supra, n. 81. Cf. Phelan v. Back [1972] 1 All E.R. 901 (Q.B.D.) where a recorder of quarter sessions, at the close of the appeal before him, recalled a prosecution witness to refresh his memory (a shorthand note not being available), and asked both counsel to cross. examine and address the court further (both invitations being declined) and it was held that this was a proper exercise of his discretion.

ss Id. at 369.

86 (1953) 37 Cr. App. R. 32.

87 (1967) 51 Cr. App. R. 230, [1967] 1 All E.R. 989. In distinguishing Tregear, the court in Cleghorn, supra, n. 77 at 998 (All E.R.) said that the trial judge's conduct in calling the witness in Tregear was proper because "it was really at the request of the defence that the witness was to be called", not as a witness of the court.

BR Id. at 289. 
In a murder appeal where it was alleged that the trial judge unduly interrupted counsel and prevented him from opening his defence to the jury, the court said that although the trial judge's comments were "strong" they were justified upon the evidence and defence counsel has the right to open his case before calling evidence where he is calling witnesses other than the accused.89 After a jury retired, they returned to court and asked that a witness answer a question; the witness was recalled, and questioned by the trial judge, but the accused was not given the opportunity to cross-examine the witness nor of rebutting that evidence (or to address the jury on same), and the conviction was quashed. ${ }^{90}$ Where the accused did not put his character in question, and the presiding judge inferred he had information about the accused's background and put a series of questions to the accused about his character, the court said this was improper; ${ }^{91}$ and a new trial was ordered where the presiding judge in questioning the accused about his explanation concerning possession of money also inquired about his past history, which necessitated defence counsel bringing out the fact of the accused's prison record. ${ }^{92}$

What are the limits of a trial judge's right to cross-examine an ac: cused? It has been put this way ${ }^{93}$ (and it has been held that these' observations apply to any witness for the prosecution or defence):94

The Judge began by doing something of which no one could complain. It was a long case, and he had taken a careful note, and it was quite right, so long as counsel for the defence had no objection, that the judge should put to the defendant when giving evidence the various allegations of the witnesses for the prosecution, in order that he might deal with them. So long as they were put colourlessly, no one could object. Indeed counsel for the defence might have thought it assisted him in his task. There is no reason why the Judge should not from time to time interpose such questions as seem to him fair and proper. It was, however, undesirable in this case that, beginning in the way which I have described, the Judge should proceed, without giving much opportunity to counsel for the defence to interpose, and long before the time had arrived for cross-examination, to cross-examine (the co-defendant) with some severity. The court agrees with the contention that that was an unfortunate method of conducting the case. It is undesirable that during an examination-in-chief the Judge should appear to be not so much assisting the defence as throwing his weight on the side of the prosecution by cross-examining a prisoner. It is obviously undesirable that the examination by his counsel of a witness who is himself accused should be constantly interrupted by cross-examination from the Bench. Cross-examination in cases of this kind is usually quite efficiently conducted by counsel for the Crown.

\section{A judge who intervenes during an examination-in-chief: 95}

... with questions which may seem to the jury to suggest that the evidence of the witness, although given on oath, is not to be believed, [then] it is also necessary that the Judge should remind the jury that the question of believing or not believing any particular witness is, like all other matters of fact in a criminal trial, a question for them and not for him.

Even where the defence is "fantastic or devoid of merit" the trial

s9 IIill (1912) 7 Cr. App. R. 1.

90 Howarth (1918) 13 Cr. App. R. 99.

91 Ratcliffe (1919) 14 Cr. App. R. 95 as this line of questioning contravened s. 1 (f) of the Criminal Evidence Act, 1898.

92 Taylor (1934) 25 Cr. App. R. 46.

${ }_{93}$ Cain (1936) 25 Cr. App. R. 204 at 205.

9s Bateman (1946) 31 Cr. App. R. 106 at 113.

93 Gilson; Cohen (1944) 29 Cr. App. R. 174. 
judge, Goddard L.J.C. said in Clewer, ${ }^{96}$ should "treat it with the same consideration as he would pay to a defence not marked by these characteristics." And he continues:97

If counsel is constantly interrupted both in cross-examination and examinationin-chief, and, more especially ... during his speech to the jury, his task becomes impossible.

Goddard L.J.C. points out that when an improbable defence is raised, defence counsel has a difficult task but should be allowed "to do his best in presenting his case, leaving it to the judge to deal with, and maybe to demolish it in his summing-up";98 nor should the trial judge in the presence of the jury suggest that defence counsel is "raising false issues"; 99 nor should he indicate that he has made up his mind against the accused on the basis of a "defence ... devoid of any foundation."100 The trial was irregular, and the court concludes:101

The prisoner is entitled to have his defence, even the most improbable, put to the jury by his counsel, whose task is rendered impossible if he is constantly subjected to .... interruptions. Moreover, to have his final speech interrupted for so long a period, and on so many occasions [ 15 or 16], is a most disconcerting experience....

No matter how hopeless the defence may appear to be to the trial judge, Lord Hewart's stricture about the necessity for both the doing of justice and its concomitant appearance must be borne in mind by the judiciary; hence where a trial judge fails to apply that principle, even though the evidence of guilt is clear, a conviction will be quashed as in Regina v. Barnes. ${ }^{102}$ While the jury was out, the presiding judge told defence counsel that he takes "a very serious view of hopeless cases, without the shadow of a defence, being contested at public expense", 103 and he went on to discuss the long court lists of cases. Defence counsel said he had given his client advice and asked to withdraw, and the trial judge told accused he would have to go on by himself because he would not grant him an adjournment. Accused, no doubt realizing his plight, then said he would carry on with his counsel, and he remained firm with his Not Guilty plea.

The Court of Appeal (Criminal Division) castigated the trial judge's conduct and, notwithstanding the fact that all of the foregoing took place in the absence of the jury and that the evidence to convict the accused was clear and beyond any doubt, Lord Parker L.C.J. (for the court) said that the trial judge's pressure to get a guilty plea from the accused, and the impossibility of defence counsel properly conducting a defence under these circumstances (where the trial judge expresses such views) were sufficient to quash the conviction because: 104

There are cases, of which this is one, in which the principles involved are more important than the case itself.

96 (1953) 37 Cr. App. R. 37 at 40.

97 Id.

98 Id.

Id. at 41 .

$100 \mathrm{Id}$.

sol Id. at 42.

102 [1971] Cr. App. R. 100. See Doing Justice to Justice, 120 The New Law Journal 1126 (December 10, 1970, Pt. 5).

103 Id. at 103.

$10+$ Id. at 108. Whenever we read of criminal appeals being dismissed, notwithstanding errors, omissions and defects in the trial process because there has been no substantial miscarriage of justice, as our courts are wont to put it, one.should remind oneself of these words. 
Lord Parker L.C.J. outlined five reasons concerning the trial judge's improper conduct: ${ }^{105}$

(1) there was extreme pressure put on the accused to plead guilty;

(2) accused was bound to believe that the judge's adverse view would not result in a fair trial;

(3) the judge interfered with the independence of counsel in giving his client his best advice (by suggesting what the advice ought to be);

(4) by indicating what counsel's advice was, "the relationship of confidence between client and counsel"106 was destroyed; and

(5) the trial judge should have granted accused an adjournment, thereby not "forcing [him] to continue with counsel in whom he no longer had full confidence."107

An interesting sidelight is the treatment accorded the trial judge's comment about the lengthy court lists of hopeless cases being tried at public expense. Lord Parker said that one can have "great sympathy" for the trial judge's views, but "as the law stands, it is an accused person's right to have counsel under legal aid to defend him should he elect to plead Not Guilty."108

\section{Canada}

Canadian courts dealing with the role of the trial judge emphasize that while there is an appropriate place and time for his intervention in the trial, and while he has the right to summarize and comment upon the evidence in a jury trial so long as he makes it clear that the jury are the sole judges of the facts, the prime prerequisite is that there must be a fair trial for the accused ${ }^{109}$ wherein the trial judge is not an umpire; nor should he assume the role of counsel for the defence or the prosecution (although when the accused is not represented his function is more all-embracing than that) or make remarks before the jury prejudicial to the accused such as indicating his conviction of the accused's guilt.

An eminent Canadian jurist, O'Halloran J.A. in Regina v. Pavlukoff 110 lucidly explained the role and function of the trial judge in a statement worth quoting in extenso, and he concludes the following remarks by pointing out that judges are human and not objective-scientific recording machines, the "jury is not apt to reason in the abstract as if all men were alike, and attempt to force life into a plaster cast of law"111 and a judge does have a powerful influence upon the jury. ${ }^{112} \mathrm{He}$ states: ${ }^{13}$

But the course of this case at trial and the argument on appeal demands the unpleasant appellate duty of adding two observations in a public interest that is con-

\footnotetext{
105 Id. at 106, 107.

106 Id. at 106.

${ }_{107}$ Id. at 107 .

10n Id. at 104: would that other trial judges who are concerned with efficiency and clearing up trial lists, take heed of these words.

103 As stated by Goddard L.J.C. in Clewer, supra, n. 96 at 40.

110 (1953-54) 10 W.W.R.(N.S.) 26 (B.C.C.A.).

III Id. at 43.

112 Id. at 44

113 Id. at 40-43. Consider also the views of Corner, The Trial Judge, His Facial Expressions, Gestures and General Demeanor-Their Effect on the Administration of Justice, (1967-68)6 American Criminal Law Q. 175 at 178 who points out that a judge is human, and even if he has a "poker face" he cannot "remain completely indifferent" during the trial, and "will react to the happenings just as any other person would and his facial expressions will convey thoughts to the minds of the jurors. It is this silent language on the part of the trial judge which frequently controls the thinking of the jury."
} 
cerned with whether the processes of the common law shall decay or flower with a new vigour. The first is that a judge sitting with a jury is to a large degree an umpire and ought not to usurp the functions of Crown counsel or appear to the spectators as a crusader for the conviction of a man on trial for his life. It may be that in some cases failure of counsel acting for the Crown to ask questions that ought to be asked may impel the judge for the assistance of the jury to interject himself into examination or cross-examination to a degree that he does not like to do and would not do if aided by experienced counsel. But that could not apply to this case, where counsel for the Crown as well as for the defence are well-known leaders of the bar, skilled in the practice of the criminal law. Experienced counsel for the Crown did not need judicial assistance in carrying on his cross-examinations.

The second observation springs from the discussion of the extent to which a judge may express to the jury his own view of the credence to be attached to the testimony of a witness or directly or indirectly make clear his belief upon any factual phase of the case which would indicate his own conviction that accused is guilty. There seem to be some generalized judicial dicta on the point, largely favouring a wide licence to the judge, and perhaps much more so traditionally in England than in Canada. There may be a view that the judge may express his own personal opinions to the jury as often as he wishes, provided that on a corresponding occasion he repeats to the jury the formula that 'the facts are for them alone'. With great deference and I hope with proper humility, in view of the eminence of some of the jurists who have given voice to dicta of apparently wide scope, I think it is appropriate to express a rationalized view that since the question of guilt is solely for the jury, a judge, under Canadian jurisprudence at least, who expresses his own opinions to a jury is doing nothing else than attempting to usurp the functions of the jury, the more so if strong and stubborn preconceptions are freely ventilated in the hearing of the jury prior to the conclusion of the defence case.

If the guilt is solely for the jury, and the judge in law so instructs them, what occasion can there be for the judge to express his own opinions as to factual matters of guilt?

It seems an absurdity for a judge, after telling the jury the facts are for them and not for him, then to volunteer his opinions of facts followed then or later by another caution to the jury that his own opinion cannot govern them and ought not to influence them. If his opinion ought not to govern or influence the jury, then why give his opinion to the jury? To a person who is not a lawyer, but has some training in the science of correct thinking and some knowledge of the workings of the human mind, a judge who expresses his own opinions to the jury is in effect unconsciously perhaps but nevertheless subtly and positively undermining the plain instruction he has given the jury that 'the facts are for them and not for him;' in reality he is in true effect attempting to persuade the jury not to exercise their own minds freely (as in law he has told them they must do) but instead to be guided by the factual conclusions he volunteers to them.

The judge in court officially and physically occupies a position of great power and prestige. His power and his control of the trial, which can be plainly seen in court, are matched by his knowledge of the law and his experience in weighing and analyzing evidence. His lightest word or mannerism touching the reliability of a witness and the guilt of the accused cannot fail to bear heavily upon the members of the jury who naturally look up to him (and in more ways than one) as the embodiment of the great traditions of the law. To the jury the presiding judge appears as the great neutral. Anything that emanates from him carries for them at least all the ear-marks of balanced justice. In a widely publicized murder trial his every act and word are subjected to a merciless public scrutiny, which often wonders if he possesses natural penetrating shrewdness accompanied by a disciplined compassion.

There is every reason why the judge should confine himself strictly to his own responsibilities and leave the members of the jury alone to carry out their responsibility. There may be a tendency among some judges perhaps to feel constantly nervous whether a jury will bring in the verdict they may think the jury should bring in. But the law does not give the judge such a superior position. On the contrary the matter is beyond his jurisdiction and solely with the jurisdiction of the jury. The presiding judge is not an appellate court 'writ small'. It might easily be inferred that a judge who persists in giving his opinions to the jury is thoroughly convinced that a jury is not as competent as the judge himself to come to conclusion of the facts. 
In a criminal case the trial judge can call witnesses. The position has been explained in this way in Rex v. Skelly: ${ }^{114}$

As McDermott's name was endorsed on the indictment, the prisoner's counsel had the right to place him in the witness-box for examination. The prosecutor is not bound to call witnesses merely because their names are on the back of the indictment, but the prosecutor ought to have all such witnesses in court, so that they may be called by the defence if wanted. If, however, they are called by the defendant he makes them his own witnesses: per Alderson B., in Regina v. Woodhead (1847) 2 C. \& K. 520 .

The trial judge also, in the exercise of his discretion, might have called any witness whose name was on the indictment, as was done by Littledale J. in Rex v. Beezley (1830) 4 C. \& P. 220, and by Patteson J. in Regina v. Holden (1838) 8 C. \& P. 606 at 610 .

The trial judge cannot interfere with the Crown's right to determine which material witness to call, even where his name appears on the back of an indictment, especially where the Crown decides not to call such witness deeming him to be unreliable.115

While the trial judge (and the Crown) need not provide witnesses for the accused, he should see to it that the Crown informs the accused so that the accused has "knowledge of the witnesses who are to be called against him and the general character of the evidence they are to give".116 A trial judge need not inform an indigent accused who requests assistance that the Crown will assist him in obtaining required

114 (1927-28)61 O.L.R. 497 at 500 per Latchford C.J. In Beezley, supra, n. 69 Crown counsel closed his case, but Littledale J. directed that four witnesses whose names were on the back of the indictment should be called to permit cross. examination by defence counsel; and after the witnesses were called and cross-examined by defence counsel, Littledale J. restricted Crown counsel to re-examination on matters arising out of cross-examination. In Holden, supra, n. 70 Crown counsel said he was not going to call a certain witness whose name was not on the back of the indictment, and Patteson J. said (173 E.R. 638 at 640 ):

She ought to be called. She was present at the transaction. Every witness who was present at a transaction of this sort [murder] ought to be called, and even if they give different accounts, it is fit for that the jury should hear their evidence, 80 as to draw their own conclusion as to the real truth of the matter.

The witness was then called and gave evidence. See also Newark and Samuels, supra, n. 61 at 399, 400; Popple, Annotation, Calling Witnesses at a Criminal Trial, (1951) 12 C.R. 76. In Rex v. Gilbert (1950) 9 C.R. 372 at 381 , [1950] 1 W.W.R. 923, [1950] 2 D.L.R. 841, 96 C.C.C. 337, Parlee J.A. of the Alberta Supreme Court Appellate Division said that "it appears that the right of the presiding judge and of the Crown to call witnesses after the close of the case for the defence is one largely in the discretion of the trial judge". (Emphasis is mine.) Note that this additional limitation on the right of the trialjudge to call witnesses, i.e. only after the defence closes its case, does not come from Skelly, Beezley or Holden. Parlee J.A. does refer to Rex v. Crippen, supra, n. 71; Rex v. Sullivan, supra, n. 84; Rex v. Harris, supra, n. 74; and other authorities for this statement. Where in a jury trial, the presiding judge, of his own motion called a witness, who had no personal knowledge of the event, to re-enact that event, it was held that this was improper as it could prejudice a fair trial by presentation of evidence "in a much more vivid and forceful manner" than the oral evidence of other witnesses: Regina v. Dilabbio [1965] 2 O.R. 537 at 539, [1965] 4 C.C.C. 295, 46 C.R. 131 (C.A.).

11 Lemay v. The King [1952] 1 S.C.R. 232 at 238-241, 14 C.R. 89, 102 C.C.C. 1; Rex v. Schneider [1927] 1 D.L.R. 999 (Sask. C.A.); R. v. McClain (1913) 7 W.W.R. 1134, 23 C.C.C. 488,8 Alta. L.R. 73, 23 D.L.R. 312 (C.A.); and Reg. v. Byrne (1953) 16 C.R. 133 at 136 (B.C.C.A.). As to Crown counsel's duty to disclose to the defence names of witnesses who are to be called against the accused see Childs v. The Queen (1959) 29 C.R. 75 at 80 (N.B.S.C.). The Crown is not under a duty to call all witnesses who gave evidence at the preliminary hearing: Regina v. Taylor (1971) 1 C.C.C. (2d) 321 at 330, 331 per Dickson J.A. (Man. C.A.). At a trial the prosecution's discretion in calling or tendering witnesses for cross-examination, whose names appear on the back of an indictment, must be exercised properly: $R$. $v$. Oliva [1965] 3 All E.R. 116 at 122. In Lemay at 240 (S.C.R.), Kerwin J. refers to Adell Muhammed v. A.G. for Palestine [1944] A.C. 156 where Lord Thankerton suggests that the remarks of Lord Hewart in Rex v. Harris, supra, n. 74 that the prosecution in a criminal case must call all material witnesses, must not be taken as derogating from "the long-established right of the prosecutor to exercise his discretion to determine who the material witnesses are". The statement by Lord Roche in Seneviratne v. Rex [1936] 3 All E.R. 36 at 49, 3 W.W.R. 360 at 378, that those witnesses "essential to the unfolding of the narrative on which the prosecution is based must ... be called by the prosecution" has to be considered in the context of this right of the prosecutor, Kerwin J. explains (at 238-241, S.C.R.). In Lemay at 241 Kerwin J. states that the "Crown must not hold back evidence because it would assist an accused. ..." See Practice Notes (1951) 12 C.R. 74 at 81; and Rex v. Agostino (1951) 12 C.R. 93, 100 C.C.C. 380 (B.C.C.A.); aff'd [1952] I S.C.R. 259, 14 C.R. 113, 102 C.C.C. 112. In administrative proceedings, where penal consequences may prevail, it has been held that the tribunal may call an alleged "offender" and receive his evidence even where his responses to queries from the tribunal tend to incriminate him: Rex v. Pantelidis [1943] 1 D.L.R. 569 (B.C.C.A.).

116 Regina v. Cunningham (1952) 15 C.R. 167 at 174, 175 (N.B.C.A.). In this case accused objected (at 174) that the trial judge failed to inform him of the "probable evidence of four prosecution witnesses previous to their being called whose names do not show on the back of the indictment". 
witnesses.117 A trial judge can ask how an accused pleads, and "if the reply is not a clear admission of all the elements of the crime" he "must proceed to inquire into the charge without further questioning".118 Once the Crown closes its case, it is within the trial judge's discretion whether he will permit the Crown to re-open its case, as, for example, where the defence does not call evidence and the Crown motion to re-open is not based upon "any change of position on the part of the defendant, nor of the discovery of fresh evidence by the Crown." 119

A trial judge should not be in a hurry to complete the proceedings. ${ }^{120}$ The limits of his intervention and his duties were delineated by Ferguson J.A. in Rex v. West, ${ }^{121}$ where he said:

We do not doubt that, objectionable as it may be, the trial judge has a right to ask leading questions, also to endeavour to speed the trial, and even to tell counsel that he is wasting time, and that he also has the right to suggest . . . that counsel waive their rights to address the jury. These ... are matters of discretion and good judgment, not entitling us to interfere unless we are of opinion that they re sulted in a manifest injustice being done to the accused.

To the same effect is the statement by Schultz J.A. of the Manitoba Court of Appeal in Regina v. Ignat: ${ }^{122}$

\begin{abstract}
Unquestionably, dilatory tactics and unnecessary delays, frivolous and pointless questions, are time-wasting and are properly subject to comment, restriction and control by the trial judge. He sits to hear and determine the issues and, subject to the rules of procedure and precedent, he has the sole control of his court. He has the duty to insist that the rules of evidence be observed; to intervene to clear up points when necessary for his own information, or to discourage irrelevancies; but such interventions must be justified by the circumstances under which they are made.
\end{abstract}

A compendium of a trial judge's functions would read as follows: he should not intervene inordinately during the trial; ${ }^{123}$ he should keep control of the proceedings, and should not, for example, permit the jury to examine and cross-examine witnesses; ${ }^{124}$ he should not usurp the function of counsel;125 within the bounds of proper advocacy he should allow counsel to proceed with the continuity of examination and crossexamination;126 and should give the fullest opportunity of cross-examina-

117 Id. at 178 .

118 Rex v. Lee (1926) 45 C.C.C. 280 at 282 (B.C.S.C.).

119 Rex v. Ash-Temple Limited et al. (1949) 93 C.C.C. 267 at 278, 8 C.R. 66, [1949] O.R. 315, [1949] O.W.N. 158 (C.A.). See also R. v. Perreault (1942) 78 C.C.C. 236 (Que.); R. v. Kishen Singh [1941] 2 W.W.R. 145, 76 C.C.C. 248, 56 B.C.R. 282, [1941]3 D.L.R. 341 (B.C.C.A.); Rex v. Gregoire (1926-27) 60 O.L.R. 363; and Regina v. Fahlman Champagne and McManus (1969-69) 5 C.R.N.S. 192; aff'd (1969) 70 W.W.R. 438, (1969.70) 8 C.R.N.S. 245 (B.C.C.A.) where the trial judge allowed the Crown to re-open its case (the defence having closed its case) to tender viva voce evidence by an analyst concerning marijuana after it was found that the analyst's certificates tendered by the Crown were inadmissible and defective in form, and Cleghorn, supra, n. 77 and Tregear, supra, n. 87 were held inapplicable in the circumstances; i.e., it was not a case concerning the Crown's right to call the rebuttal or reply evidence, but rather involved special circumstances-the Crown mistakenly believing that the defence had accepted the certificates as evidence-and in the interests of justice, and as there was no prejudice to the accused, the trial judge exercised his discretion properly in allowing the Crown to re-open its case.

120 Regina v. Ignat (1965) 53 W.W.R. 248. At a preliminary hearing the presiding judge has a discretion whether or not to grant an adjoumment: Regina v. Fauteux, Ex Parte Morgentaler (1971) 3 C.C.C. (2d) 187 at 194-196 (Que. Q.B.).

121 (1925) 57 O.L.R. 446 at 448, 449; and approved of in Rex v. Gibbons [1946] O.R. 464 at 480 (C.A.).

122 Supra, n. 120 at 250.

123 Regina v. Pavlukoff, supra, n. 110 at $34 ;$ Regina v. Muggli (1961) 131 C.C.C. 363 at 376 (B.C.C.A.); and Regina v. Ignat, supra, n. 120 at 251 . There is no rule or practice which requires the trial judge to make a ruling in a criminal case as to the order in which defence witnesses are to be called, nor need the accused be called first for the defence: Regina v.Smuk (1971) 15C.R.N.S.218, (1971)3C.C.C.(2d) 457 (B.C.C.A.).

124 Regina v. Muggli, supra, n. 123 at 390,392 . Where counsel, during a trial, approached the Bench and had a discussion with the trial judge which neither the accused nor the jury could hear, it was held that this is not improper as the trial judge did nothing to advance the case in the absence of the accused: Collin v. The Queen (1968-69) 5 C.R.N.S. 201 (Que.Q.B.).

125 Regina v. Pavlukoff, supra, n. 110 at 34.

120 Regina v. Ignat, supra, n. 120 at 250; and Regina v. Viger(1959) 29 C.R. 302(Ont. C.A.). 
tion, so long as the right is not abused by prolix, irrelevant, insulting questions; ${ }^{127}$ and should not stop a trial without hearing all the available evidence, nor prejudge the outcome of the trial:128 nor should he indicate that he favors the prosecution or the accused ${ }^{129}$ or take the initiative by acting as counsel for the prosecution, ${ }^{130}$ which has been aptly stated by Rivard J. in Regina v. Denis: ${ }^{131}$

There is no doubt that a judge presiding over the criminal assizes has the right to intervene during the trial and to ask the witnesses questions. He has the right, and often the duty, to do this when it is necessary to clarify an answer, to render more precise a vague statement, or to remove the ambiguity from a comment. These interventions, however, must never leave the jury with the impression that the judge's opinion has been formed or that he does not believe a witness's statements, which statements could be favourable to the accused.

During the examination of the witnesses, the judge must not intervene in such a way as to place the weight of his authority behind either the Crown or the defence. When he does intervene, moreover, he must not ask questions which might give the jury the impression that he is suggesting to them that they should not believe the witness. Credibility of witnesses is a matter which falls to be decided entirely by the jury alone, without the judge's intervention.

It is irregular, unjust, and consequently unlawful for a judge in the trial of a case to lead the jury to believe that he is convinced of the guilt of the accused. Furthermore, the influence of a judge presiding over criminal assizes on the jury must not be underestimated. The jury is usually convinced, and with good reason, that the judge, who is accustomed to the proceedings taking place before them, and about which they know practically nothing, is the best guide for them to follow in the execution of their duty. In so far as questions of law are concerned, this is true, but it is not the case when the jury comes to analyze the facts presented to them. A question asked by the judge from the Bench, containing an analysis of evidence already given, or containing a statement of facts which have not been proved, certainly exerts a much greater, influence on the jury than any cross-examination, however severe, which may be carried on by counsel.

The law prohibits the judge participating in the examination of witnesses where such participation is likely to indicate to the jury a predisposition in the judge's mind toward one side or the other. This would amount to the exercise of undue influence over the jury in the area of its own duties and jurisdiction.

The discretion of the trial judge to intervene, either to clarify an obscure answer, or to avoid the misinterpretation of an answer, is in many cases a matter of degree, and where the trial judge participates to excess, the line of demarcation between the lawful and unlawful conduct of the trial is drawn.

It is unlawful for the judge, during the conduct of a trial to usurp the function of counsel for the Crown. In many cases, the intervention of the judge wishing to make an answer clear and intelligible, or to move the trial further in the direction of an area which he considers important, is desirable, but it must be remembered that all such interventions are subject to the over-riding principle that none of the parties must have reason to believe that they have not had a fair and impartial trial.

During a trial (civil or criminal) the presiding judge need not be mute; 132 but this does not give him a licence to make offensive or prejudicial remarks with respect to the accused or his case. ${ }^{133}$

${ }^{127}$ Rex v. Rewniak (1949) 7 C.R. 127 (Man. C.A.) (annotation by A. E. Popple 136-140); Regina v. Muggli, supra, n. 123 at 376 ; and Regina v. Ignat, supra, n. 120 at $250,251$.

I2n Regina v. Viger, supra, n. 126 at 306; and Regina v. Ignat, supra, n. 120 at 251.

129 Rex v. McCarthy (1940) 57 B.C.R. 155 at 156, 157 (B.C.C.A.); Rex v. Dairlyn [1947] 1 W.W.R. 449 at 458,459 (B.C.C.A.); Regina v. Muggli, supra, n. 123 at 402; and Regina v. Denis [1967] 1 C.C.C. 196 at 197, 202, $203,214,215$.

130 Regina v. Denis, supra, n. 129 at $208,214$.

131 Id. at 202, 203.

132 Regina v. Paulukoff, supra, n. 110 at 32.

1at Regina v. Paulukoff, supra, n. 110 at $35-37$ where the trial judge said it was fortunate for the accused that the matter was in the jury's hands and not his, and the appeal court held that if there was prejudice this was overcome by telling the jury they were the sole judges of the facts; Regina v. Bevacqua and Palmieri [1970] 2 O.R. 786 (Ont. C.A.) where the Provincial Court Judge, during accused's examination, said he "should go back to Italy", the majority of the court 
When he sums up for the jury he should not merely repeat or summarize the evidence, 134 "nor should [he] place his own constriction upon the evidence or otherwise usurp the function of the jury ... [but] the judge ought to make clear to the jury, in a way they cannot fail to understand, what are the determinative factual issues in dispute, upon which proof of guilt must stand or fall."135

In this summing-up he must set out the accused's position and the evidence in support of it; ${ }^{136}$ he should present to the jury any defence that may arise from the evidence, whether or not it is raised by defence counsel,137 and tell the jury that they are the sole judges of the facts which does not preclude him from expressing his personal view as to the character of police witnesses, ${ }^{138}$ or from commenting upon the credibility of witnesses ${ }^{139}$ (but he must not do so during the testimony of the witness);140 and he need not spend the same amount of time, in his summing-up, for the defence and prosecution. ${ }^{141}$

The trial judge is in a special position when the accused is not represented by counsel, and it has been said that the court "in effect acts as counsel for him and is vigilant to see that nothing is done that would prejudice him"; ${ }^{142}$ and "the court shall extend its helping hand to guide him throughout the trial in such a way that his defence, or any defence the proceedings may disclose, is brought out to the jury with its full force and effect."143

\section{ASSESSORS AND EXPERTS}

In Phillips, ${ }^{144}$ Evans J.A. says that an expert, under Rule 267, is appointed "solely to assist the judge in understanding the evidence"145 and the "drawing of inferences, the deciding of issues, the interpretation of the so-called phenomenon and the reaching of conclusion are all matters within the exclusive jurisdiction of the trial judge and cannot be delegated". ${ }^{146} \mathrm{He}$ continues: ${ }^{147}$

I do not think that a court can say, in effect, 'I believe that this accident resulted from some unusual circumstance and I propose to call in an expert to assist me in discovering the cause.' Such a procedure is inquisitional rather than judicial.

The expert is not a judicial officer charged with the responsibility of determining matters in issue, nor is he a Court-appointed investigator empowered to advance possible theories and state, as conclusions of fact, opinions based on matters not advanced in evidence.

said the remarks were "beyond comprehension" and "utterly disgraceful" but felt the conviction should stand; however, Laskin J.A. dissenting, indicated the remark was suggestive of an unfair trial because of the Judge's prejudice.

134 Rex. v. Harrison (1950) 11 C.R. 250 (B.C.C.A.); and Rex v. Newell(1942) 77 C.C.C. 81 at 85 (Ont. C.A.).

13s Rex v. Harrison, supra, n. 134 at 253 per O'Halloran J.A.

136 Rex v. West, supra, n. 121 at 450.

137 Regina v. Hladiy [1952] O.R. 879, (1952-53) 15 C.R. 255 at 260 (and see annotation by A. E. Popple, 262-264), 104 C.C.C. 235 (C.A.).

13s Forsythe v. The King[1943]S.C.R. 98 at 101.

139 Rex v. Newell, supra, n. 134 at 85, 86; and Rex v. Olson [1929]2 D.L.R. 300 at 302, 303 (Sask. C.A.).

140 Regina v. Augello and Tascarella [1963|3 C.C.C. 191 at 192(Ont.C.A.).

141 Regina v. Muggli, supra, n. 123 at 368.

142 Rex v. DeBertoli [1927] 2 W.W.R. 300 at 303, appea] dismissed on other grounds [1927] S.C.R. 454.

${ }^{143}$ Rex v. Darlyn, supra, n. 129 at 452. See also Regina v. Doyle (1962) 38 C.R. 1 (B.C.C.A.); and Regina v. Hueb. schwerlen (1965) 45 C.R. 393 (Yukon Terr. C.A.).

114 Supra, n. 1.

14 Id, at 660 .

146 Id. at 661 .

147 Id. 
The expert, he explains, should not examine, nor cross-examine; he is not a partisan advocate; a Court-appointed expert explains the evidence, as adduced in his special field, so that the trial judge may better comprehend complex factual matters, ${ }^{148}$ and he concludes that he doubts that a person appointed under Rule 267 is an assessor; more properly he should be called an expert. ${ }^{149}$

Although Ontario courts have used Rule 267 to obtain expert assistance, ${ }^{150}$ from persons who have been called assessors, it now appears that in the light of Phillips trial judges will have to be more careful when using this Rule.

Brazeau v. Wilson ${ }^{151}$ involved a claim upon a building contract (installation of a heating system), and on the appeal Meredith C.J.C.P. suggested that since the evidence adduced was not satisfactory, had he heard the trial, he would have used what is now Rule 267 "to appoint some competent person to make the necessary examination of the work in question and give an impartial report, and, if necessary, give evidence, upon the matters in question. ..." In the same vein we find courts suggesting the use of this Rule where there is lengthy evidence with respect to "faulty execution of building contracts";152 obtaining a report from a firm of television experts concerning the quality of a number of television sets; ${ }^{153}$ and with the consent of the parties, using a doctor to assess complicated medical evidence. ${ }^{154}$

If Rule 267 is properly used, where there is extensive, complex evidence, the trial judge can profit from the assistance of an expert; however, even before the restrictions suggested in Phillips there was a reluctance by trial judges to avail themselves of the utility of this procedure, which has been attributed to the "mystique and sanctity of the adversary procedure."155

\section{AN EVALUATION}

The foregoing discussion has dealt with the civil and criminal trial process separately; and this is partly due to ease of organization of the material; and partly because this is an obvious division. ${ }^{156}$ It is trite to say that basically the rules of evidence in criminal and civil trials are the same. This is subject to obvious differences, e.g., the standards of proof required, and statutory requirements. ${ }^{157}$

Having said this one could leave the subject of division of the material, but there are even more compelling reasons for this division. Chan-

\footnotetext{
148 Id at $661,662,663$.

149 Id. at 663 and he says that there are rare instances when an expert may be allowed to ask a question of a witness, in which event the questions become those of the judge and he accepts "responsibility for them".

150 Blowes v. Hamilton, supra, n. 2. See also the Mechanics' Lien Act, R.S.O. 1970, c. 267, 8. 46(3) which allows the judge or officer who has jurisdiction to try the action to obtain the assistance of experts, such as a merchant, accountant, actuary, building contractor, architect, engineer "or person in such way as he deems fit, the better to enable him to" determine any matter of fact in question. ...."

151 (1916) 36 O.L.R. 396 at 397.

152 House Repair and Service Co. Limited v. Miller (1921) 49 O.L.R. 205 at 207 per Hodgins J.A.

1s3 MacDonald Electric Limited v. Cockrane [1955] O.W.N. 255 per Aylen J.

15i Richard v. Gray Coach Lines Ltd. [1950] O.W.N. 136 per MacKay J.

135 Schiff, The Use of Out-of.Court Information in Fact Determination at Trial, (1963) 41 Can. Bar Rev. 335 at 373.

156 No attempt has been made to treat the subject-matter on the basis of the different role the trial judge plays in a jury trial as compared with a non-jury trial: see Wyzanski, $A$ Trial Judge's Freedom and Responsibility, (1952) 65 Harv. L. Rev. 1281.

157 The Criminal Code, R.S.C. 1970, c. C-34; Evidence Act, R.S.C. 1970, c. E-10; and Evidence Act, R.S.O. 1970 , c. 151.
} 
cellor Boyd explained the distinction between civil and criminal cases in this way: ${ }^{158}$

Though the rules of evidence may be the same in civil as in criminal cases, a wide and proper distinction exists in the application of the evidence, as to its effect, as to its extent, and as to its degree of certainty. Criminal prosecutions at the instance of the Crown, and for the vindication of public rights or public security are compulsory, and admit of no compromise .... A decision once pronounced against him is practically irrevocable, and the consequences of an error in branding as a criminal, one who is innocent cannot be effaced. Hence the safeguards which the law casts around an accused person, declaring in the language of the earlier judges that it is almost impossible to be too careful': Thompson's Case 1 Leach's C.C. 293. All these characteristic features of criminal prosecutions are wanting in civil litigation.

In civil cases the claims of competing private persons are set out in pre-trial proceedings (pleadings, discovery, interlocutory motions, particulars, and so on) which define the issues; in criminal trials it is the government (it would offend the Harold Laski concept of sovereignty to use the word "state" here) which claims that the citizen has transgressed against community rules; and in civil trials pecuniary damages result, whereas in the criminal trial the result is a fine and/or gaol.

By their nature, although each is a trial, the civil and criminal trials are different, 159 and the role of the trial judge in each must necessarily differ. It could be said that in one sense the object of each is to determine facts objectively; but this feature of the trial process has been characterized as dubious. 160

Some of the dicta in both civil and criminal cases may well apply to both; however, it is suggested that a cleaner (for want of a better word) approach concerning the role of trial judges, would be for judges in civil actions to confine themselves as much as possible to the principles as set forth in civil cases, and for judges in criminal cases to look primarily to criminal case principles. In Rex v. Harris ${ }^{161}$ Lord Hewart C.J. distinguished between civil and criminal cases, and said that in a criminal case where the prosecution decides not to call a witness, the judge should not of his own motion use his discretion to call such a witness as the witness then testifies "with the imprimatur of the judge;"162 and he noted that in "civil cases the dispute is between the parties and the judge merely keeps the ring" which drew the ire of Wigmore who said: "This philosophy is not only low in its standard, but is false to the conduct and status of the English judge during the last three centuries."163

Wigmore also called for the rejection of the principle laid down in In re Enoch and Zaretsky Bock \& Co., as approved of in Rex v. Harris (except that the judge does have the power to call witnesses in criminal cases) and a return to the principle stated by Edmund Burke, ${ }^{164}$ namely, that the judge's duty is "to receive every offer of evidence, apparently

\footnotetext{
158 Re Monteith; Merchants Bank v. Monteith (1886) 10O.R. 529 at 545 (C.A:)

130 Wyzanski, supra, n. 156 at 1291 says "the criminal trial is as much a ceremony as an investigation. Dignity and forebearance are almost the chief desiderata."

180 See Paul, The Legal Realism of Jerome N. Frank-A Study of Fact-Skepticism and the Judicial Process 78-91 (1959); Paul, The Role of the Judge in Jerome Frank's Philosophy of Law, (1957) 10 Okla. L. Rev. 143; Slayton, A Critical Comment on Scalogram Analysis of Supreme Court of Canada Cases, (1971) 21 U. of Tor. L.J.393.

161 Supra, n. 74 at590,591.

362 Id. at 591.

1039 Wigmore on Evidence 268, para. 2484, n. 1

264 Id.
} 
material, suggested to him, though the parties themselves through negligence, ignorance or corrupt collusion, should not bring it forward" since a "judge is not placed in that high situation merely as a passive instrument of parties" because "he has a duty of his own, independent of them, and that duty is to investigate the truth."165

There are differences concerning the calling of witnesses in civil and criminal cases. In the former, of course, the stakes are different; but in any event it is a difference of proceeding-in the civil case counsel for the plaintiff develops the case as he wants, but in a criminal trial the prosecution has a duty to call all witnesses it considers fit for the prosecution, subject only to the limitations that

(a) it should make the defence aware of all of its witnesses, and

(b) that it need not call witnesses it considers unreliable. ${ }^{166}$

In civil cases the trial judge with the consent of counsel may call witnesses; but in criminal cases, in the situations discussed, we have seen that a trial judge may of his own motion call witnesses.

In Ontario, cases concerning the custody of children may not involve the adversary system, where there is no contest and no trial of any issue, as the presiding judge may make an order for custody and access; ${ }^{167}$ but before making any order the court may require a report from the Official Guardian. ${ }^{168}$ Judicial discretion in custody applications is broad in scope and profound in its effects. ${ }^{169}$

It frequently happens in a custody case that each parent gives a great deal of evidence both in chief and under cross-examination as to the deficiency of the other spouse and only collaterally mentions the children. When the process of examination and cross-examination is complete, a trial judge should be able to ask (and it should be expected of him) each spouse what his or her plans are for the maintenance and education of the children. If the inquiry is conducted in a neutral way, this would not offend any legal strictures, and should assist in the determinative processes of the court. Would it be too broad an extension of his role and duty for him to insist upon the calling of evidence concerning the spouses (their doctors, employers) and the upbringing of the children (their teachers, ministers)? As the welfare, health, happiness and status of the children is paramount, ${ }^{170}$ the trial judge should be a pilot-participant within the aforesaid boundaries.

In criminal cases too, where the defence fails to put to the jury a defence which could arise upon the evidence adduced, the trial judge, as pilot, should put that defence to the jury.171 Should he go so far as to suggest to defence counsel where there is an obvious gap or deficiency in the defence evidence that that should or could or may be developed?

So long as he does not usurp the function of counsel and refrains

\footnotetext{
165 Edmund Burke, Report of Committee on Warren Hasting's Trial, 31 Parl. Hist. 348, cited by Wigmore, supra, n. 163 at 267, para. 2484.

166 Lemayv. The King, supra, n. 115.

167 The Infants Act, R.S.O. 1970, c. 222 , s. 1(1).

168 Id. s. 1(6). Likewise in divorce actions, Ontario Rule 796 requires the Official Guardian to deliver a report where there are children of the marriage, as defined by s. 2 of the Divorce Act (Canada), R.S.C. 1970, c. D-8.

${ }^{169}$ Bradbrook, The Role of Judicial Discretion in Child Custody Adjudication in Ontario, (1971)21 U. of Tor. L.J.401.

170 McKee v. McKee [1951] 2 D.L.R. 657, [1951] A.C. 352; and Fry v. Fry [1947] 3 D.L.R. 841 at 844.

171 Regina v. Hladiy, supra, n. 137.
} 
from entering into the dust of the arena, the trial judge should be able to act in all of the aforesaid matters as suggested. If there is some substantial area which a trial judge feels should be explored to fully expose the issues, then he should invite counsel to deal with the matters which appear critical to the Bench, and if counsel refuse, then the matter will probably end there. ${ }^{172}$ Moreover, as Wyzanski says, "a court ... . cannot rely on knowledge gained dehors the record, except in so far as it comes within the narrow ambit of the doctrine of judicial notice" 173 but a judge, in certain cases, "has a duty to elicit facts in addition to those that are offered by the parties."174

Wigmore wrote that the English judge "has never ceased to perform an active and virile part as a director of the proceedings and as an administrator of justice;" 175 and he felt that the judge's right to interrogate should be left to his discretion. ${ }^{176}$ This viewpoint is obviously too broad a statement of the judge's role, in light of the jurisprudence we have surveyed; but, perhaps, it is the best overall test to apply in all actions, be they civil or criminal.

Those who would advocate a less active Bench should bear in mind the following:

(1) The adversary system is not perfect, and may tend to suppress or distort the truth. ${ }^{177}$ The inadequacies of counsel may detract from the effective operation of the adversary system; ${ }^{178}$ and unless we countenance judicial activity, as a supplement to counsels' role, the trial process may malfunction, i.e., in the superior courts (County, District, Supreme), since at the lower trial level (small claims courts, summary conviction cases before magistrates and provincial court judges, and before justices of the peace who hear minor traffic violations), there may be no counsel, and even if there is, strict adversary rules may be relaxed.

It is not too bold to admit to the fallibility of trial processes (e.g., by allowing appeals, except for the statutory restrictions such as for lesser amounts of small claims), and to admit that counsel may even err (and if his error is substantial and grave enough, relief may be obtained, certainly in criminal matters); accordingly, there should be room within the adversary system for a trial judge to intervene in a neutral and dispassionate way to bring out facts, and define and refine the issues where the adversary system malfunctions.

(2) Lord Hewart's dictum concerning the doing, as well as the appearance of justice, should not be distorted beyond its ordinary meaning. Important as the appearance of justice may be, it is not more important than justice itself. Justice must first be done, and only then be seen to be done; and justice, obviously, should not be sacrificed

\footnotetext{
172 Not necessarily though: see Tregar, supra, n. 87.

173 A Trial Judge's Freedom and Responsibility, (1952) 65 Harv. L. Rev. 1281 at 1295, 1296, n. 69.

I7" Id.at 1293 as, he says, for example, in a landlord-tenant case whether a building is a "hotel". Cf. Magruder, Thé Trials and Tribulations of An Intermediate Appellate Court, (1958) 44 Cornell L.Q.1.

1733 Wigmore on Evidence 151 (3rd ed.).

176 Id. at 153.

177 See comment by E. M. Morgan in his book review of Goldstein's Trial Aduocacy, (1935) 49 Harv. L. Rev. 1387 at 1389; Frank, Courts on Trial-Myth and Reality in American Justice (1969), (especially ch. III "Facts are Guesses" at 14-36,92,93, 151); Ulmer, Scientific Method and the Judicial Process, vii The American Behavioral Scientist 21 at 22 (December, 1963, no. 4), who says that the "judicial process, in innumerable ways, actively suppresses the search for 'truth'."

178 See critical comment by the then president of the Canadian Bar Association, A. S. Patillo, Q.C., who deprecated the appearance in court of inexperienced counsel: The Globe and Mail, September 1, 1970.
} 
for the appearance of justice. Justice should not only appear to be done, it must actually be done.

An overly active judge may give the appearance of a meddler; but equally, a passive and quiescent trial judge may give the appearance of indifference. The public may have a legitimate complaint about the appearance and doing of justice-not just against counsel-but against a Bench which renders judgments based on technical evidentiary deficiencies or errors (such as "had certain facts been proved" or "had a certain witness been called" the result might have been different). A trial judge who endeavours to assist counsel, parties, and witnesses in the proper, complete and logical development of all aspects of a case within the confines of the rules of evidence and the adversary system, neither favoring one side or the other, nor expressing any bias, but still remaining dispassionate and neutral (but not disinterested or indifferent) will gain the respect of all concerned with the administration of a viable system of justice.

(3) Law does not operate in a vacuum. Because of the interaction of the law and the public (and, hopefully, of democratically-based public opinion upon the law), it is incumbent upon the judiciary to take appropriate steps in all trial proceedings to see to it they are conducted in a fair and equitable (in the broadest sense of the word) manner. ${ }^{179}$

\section{CONCLUSION}

A trial is a trial, whether civil or criminal; but the objectives, standards of proof, and applicable statutory materials vary greatly in these two arenas. The trial judge's functions in a civil and criminal trial are substantially similar. A trial judge is not a machine-formed computer and "often perceives the facts according to his idiosyncratic biases", 180 nevertheless, in the absence of a clearer understanding of the actual functioning of the judicial mind in the decision-making process, ${ }^{181}$ and

179 As Lord Reid has recently said, the law serves the public, "the common ordinary reasonable man" who "has no great faith in theories" and so we must apply and consider common sense, legal principle and public policy in formulating our laws: The Judge as Law Maker, (1972) 12 J. Society of Public Teachers of Law 22 at 25.

180 Slayton, A Critical Comment on Scalogram Analysis of Supreme Court of Canada Cases, (1971) 21 U. of Tor. L.J. 393 at 394 citing Frank, Hutcheson and Radin. See also Davis v. Davis [1964] A.L.R. 992 at 994,995 (Supreme Court of Victoria) where Barry J. said in dealing with the matter of determining the maintenance which a husband should pay in a divorce action:

Guided by his experience, professional and otherwise, and by what the statute stipulates and by what other judges have said about similar problems, and influenced by his own standards and by such knowledge as he has of the standards recognized by the stable elements of the community, he determines what he considers is fair and reasonable in all the circumstances of the case before him. The mental processes by which he does 80 are, of course, highly complex, frequently occurring at such a level that he is not fully aware of them. It must happen, too, in a jurisdiction in which the daily pressures are heavy, and judgment is delivered ex tempore at the end of counsel's submissions, that he does not advert to all the contentions he has heard, but this does not mean he has not considered them. The need to present his reasons in an intellectually acceptable fashion, and the way in which he is controlled by judicial tradition, and the existence of an appellate system, operate, however, as a restraint on caprice or purely emotional or impulsive reactions. To paraphrase some observations by Lord Merrivale P. in $N$. v. $N$. (1928) 44 T.L.R. 324 at 327, [1928] All E.R. 462 what a judge should do is to show a degree of practical wisdom, refusing to be misled by appearances and looking at the realities (see also $J$. v. J. [1955] P.215 at 241, 242, [1955] 2 All E.R. 85; and Schlesinger v. Schlesinger [1960] P. 191 at 197, [1959] 1 All E.R. 155). It is inescapable, however, that his decision will be the product of his own personality. A similar comment is applicable, of course, to the decision of an appellate body that reviews his order.

Cf. Perelman, Judicial Reasoning, (1966) 1 Israel L. Rev. 373 at 379.

Consider the comments of the Hon. David Lewis, Q.C., leader of the N.D.P., who on Friday, May 12, 1972 said that Canadian judges generally come from the old-line establishment parties, Liberal or Conservative, and "the moment they reach the bench they think they are gods" but 80 far as he was concerned "they are ersatz gods who do not have all wisdom": House of Commons Debates, [1972] 4 H.C. Deb. 2290 and see the criticism of this statement by Hon. John Diefenbaker Q.C., House of Commons Debates, (1972] 4 H.C. Deb. 2243, 2244.

Consider also the comment of Goitein J. in Mandelbnot v. The Attorney.General (1954-58) ii Selected Judgments of the Supreme Court of Israel 116 at 201 ed. by David Goitein, The Ministry of Justice, Jerusalem, 1963, that "judges are not automata and they are not bound to follow blindly the furrow ploughed by previous generations."

181 This approach is adapted from Slayton, supra, n. 180. See also Freedman, Judges and the Law, (1962) 5 Can. Bar J. 208 at 213. 
for the moment accepting the fact that the adversary-trial system, as we know it, operates reasonably well, we should be able to accept the following:

(1) A trial should not be a laboratory, but it should embark upon the ascertaining of all relevant and material facts concerning the issues of the case.

(2) When the evidence indicates that the issues have not been adequately defined in the pre-trial proceedings, counsel should be permitted to expand, re-define and if necessary use other and wider and broader grounds of claim, subject to adjournment and full rights of amendment and examinations, and costs; and, of course, bearing in mind the need for finality to all proceedings.

(3) Where scientific or other experiments may shed light on the factfinding process, subject to the rights of counsel to define the limits of same, the trial should embrace such possibilities.

(4) With the consent of counsel, the trial judge should be able to call and re-call witnesses; and in exceptional circumstances (e.g., a custody and/or access application) he should be allowed leeway to call witnesses to clarify and expand upon areas he feels have not been adequately or properly developed.

(5) A trial judge should be able to make use of an expert where there is extensive and complex evidence so that he may better comprehend the same.

(6) A trial judge may intervene to assist the clarification of evidence, and to prevent prolix and lengthy proceedings; but his intervention should be infrequent, and should not interfere with the conduct of the trial by counsel as they want to present their cases.

(7) During the course of a trial a trial judge should never express any bias or favor for any side.

(8) In summing-up before a jury, the trial judge should deal adequately with the evidence, and while he can comment upon the credibility of witnesses, unless there are patent cases of gross manipulation of evidence by witnesses, he should leave the issue of credibility to the jury.

(9) In criminal cases, the trial judge should never of his own motion call any witness to which the defence objects; but he may call a witness in unusual circumstances (Tregear). ${ }^{182}$ In the summing-up he must deal fully with the defence theory and the evidence in support and indicate to the jury any defences which, although not presented, are available upon the adduced evidence; and he should never favor the prosecution or the accused in his comments during the trial or in the summing-up.

The trial judge can be a pilot who guides the trial along sedate, orderly lines within the confines of the rules of evidence and the applicable law. He is certainly more than an umpire, watching the sporting-theory of litigation in action; ${ }^{183}$ and he is less than a participant in that he should not enter into the fray of combat nor take on the

\footnotetext{
182 Supra, n. 87.

183 An early American case Patton v. Texas and Pacific Railway Company (1900) 179 U.S. 658 at 660 states that: ... the judge is primarily responsible for the just outcome of the trial. He is not a mere moderator of a town meeting, submitting questions to the jury for determination, nor simply ruling on the admissibility of testimony, but one who in our jurisprudence stands charged with full responsibility.
} 
mantle of counsel. The interests of justice may best be served if the trial judge can call a witness, of his own motion, who would not become the witness of either side - if this had been done in the famous Tichborne Case it might have been helpful in resolving the case more quickly. ${ }^{184}$

As Henry Cecil noted in the 1970 Hamlyn Lecture, The English Judge, ${ }^{185}$ the public puts great trust in judges and regards "a judge as a very special person". If for no other reasons than these, the trial judge is on display to the public as the epitome of our judicial system, and in his functioning it behooves him to remain fair, as objective as humanly possible, patient and willing to listen to all aspects of a case. In a sense he is a composite of the pilot, umpire and participant, with the tradition and legacy of common law. The respect which he engenders from those who appear before him is the touchstone of his success. His ability to act with equal impartiality to all who appear before him is the basic requirement of his office. ${ }^{186}$

\footnotetext{
184 Lord Maugham, Observations on the Law of Evidence with Special Reference to Documentary Evidence, (1939)

17 Can. Bar Rev. 469 at 485.

186 It has been said of Mr. Justice Haim Cohn of the Supreme Court of Israel that he "merits his Judicial Office by the wide range of his learning, by his humanism and humanity, as well as by the courage of his convictions": Helen Silving in her essay "The Morality of Advocacy" in Of Law and Man-Essays in Honor of Haim Cohn-Under the Auspices of the Faculty of Law Tel Aviv University 209 (1971) edited by Shlomo Shoham.
} 